\title{
KONSEP PENDIDIKAN KARAKTER DITINJAU DARI PERSPEKTIF PSIKOLOGI ISLAM
}

\author{
Rahimi \\ Sekolah Tinggi Agama Islam Negeri Teungku Dirundeng Meulaboh \\ Email: rahimi.plumat85@gmail.com
}

\begin{abstract}
Abstrak
Artikel ini mengkaji tentang konsep pendidikan karakter ditinjau dari pesrfektif psikologi Islam. Tujuan penulisan artikel ini adalah untuk mengetahui konsep pendidikan karakter ditinjau dari psikologi Islam. Kajian ini dilakukan dengan menggunakan studi pustaka (Library Research). Hasil dari studi ini menunjukkan bahwa pendidikan karakter merupakan pendidikan yang berorientasi pada tingkah laku dan akhlak terpuji serta tata krama yang berisikan kebiasaan sopan santun yang disepakati dalam lingkungan pergaulan antar manusia. Disamping itu, pendidikan karakter dapat dilakukan dengan membina nilainilai kemasyarakatan, kesusilaan dan keagamaan yang disatupadukan, sehingga terwujud sikap, mental, akhlak dan kepribadian yang sesuai dengan ajaran agama Islam.

Kata kunci: Pendidikan Karakter, Psikologi Islam
\end{abstract}

\begin{abstract}
The journal examines about the character education concept in terms of the Islamic Psychology Perspectif. What the intention of knowing on the character education concept in terms of islamic psychology. This study was carried out using library research methode (Library Research). The result of this research indicte that character education is that oriented towards behaviour, commandable morrals and manners that contain agreed manners in the interpersonal environment. And than character education can be done by fostering social, morals and religius value merged, so that attitude, mentallity, morals, and personality according to teaching of Islamic religion.
\end{abstract}

Keywords: Character Education, Islamic Psychology. 


\section{A. PENDAhuluan}

Arus globalisasi Informasi dan lintas geografi serta budaya semakin deras terjadi saat ini, mau tidak mau menimbulkan dampak tersendiri yang tidak selalu positif bagi kehidupan individu dan masyarakat.Berbagai perubahan yang terjadi dalam seluruh aspek kehidupan individu dimulai dari tata pergaulan, gaya hidup, bahkan hingga pandangan-pandangan yang mendasar tentang standar prilaku telah menyebabkan masyarakat jauh dari nilai-nilai moral dan telah meninggalkan karakter dari masyarakat Indonesia itu sendiri yang yang santun, bertanggung jawab dan menjunjung tinggi norma agama dan norma yang ada dalam masyarakat (Sidi Gazalba. 2001: 92).

Karakter yang berubah membawa pada kemerosotan akhlak dan moral yang menyebabkan terjadinya berbagai tindak kejahatan dan penyimpangan seperti penyebaran narkoba ke berbagai kalangan dan lapisan masyarakat, perampokan, pencurian, perkelahian antar warga, maraknya kasus pengeboman di berbagai kota, dan kekerasan massa menjadi tontonan sehari-hari.

Budaya kekerasan dan kemerosotan akhlak juga terasa di dalam dunia pendidikan. Banyak peserta didik yang sering dinilai tidak hanya kurang memiliki kesantunan baik di sekolah, di rumah dan lingkungan masyarakat, tetapi juga sering terlibat dalam tindakan kekerasan massal seperti tawuran, perampokan di atas bus kota, keterlibatan kasus obat-obatan terlarang, dan sebagainya. Meskipun kekerasan ini merupakan fenomena perkotaan, atau hanya terjadi di sekolah-sekolah yang berada di kota-kota besar, bukan tidak mungkin akan berimbas ke wilayah-wilayah lain di desa-desa (Sidi Gazalba. 2001: 92).

Untuk mengantisipasi dampak dari permasalahan yang menyangkut tentang prilaku, akhlak serta moral serta karakter dalam pendidikan, salah satu jalan yang dapat ditempuh yaitu dengan menerapkan pendidikan karakter berbasis psikologi Islam.Psikologi Islam juga mendapat perhatian dari salah seorang tokoh filosof Islam yaitu Al-Ghazali.

Psikologi Islam merupakan psikologi yang berlandaskan pada sikap hidup dan values, serta way of life yang telah digariskan dalam sudut padang ajaran Islam. Sudut padang ini kemudian merujuk pada ajaran dalam al-Qur'an, as-sunnah, sikap hidup dan nilai-nilai salafusshaleh, khzanah intelektualisme Islam, serta kontekstualisasi ajaran Islam di dalam ranah kehidupan (Baharuddin. 2005: 18).

Berangkat dari latar belakang masalah di atas penulis ingin mengkaji dan menganalisa lebih dalam lagi tentang pendidikan karakter berbasis psikologi dengan mengangkat judul jurnal yaitu: ”Konsep Pendidikan Karakter Ditinjau Dari Persfektif Psikologi Islam”.

\section{B. METODE PENELITIAN}

Dilihat dari segi pengumpulan data, metode penulisan artikel ini digolongkan ke library research yaitu suatu metode yang pengumpulan data diperoleh dengan cara menelaah bukubuku, dan rferensi referensi yang berkaitan dengan masalah yang dikaji. Untuk menganalisa penulis menggunakan pendekatan deskriptif analisis yaitu suatu metode pembahasan yang bertujuan untuk memecahkan suatu masalah dengan yakin menguraikan, menafsirkan, menyusun serta menganalisa untuk mendapatkan suatu kesimpulan. Adapun langkah-langkahnya adalah sebagai berikut: 
1. Menelaah data sesuai dengan permasalahan. Pada tahap ini penulis menelaah data-data yang ada untuk menentukan kecocokan dengan permasalahan.

2. Mengumpulkan bahan-bahan yang telah ditelaah, dikumpulkan menjadi satu kesatuan agar terhindar dari keluputan untuk dijadikan data bahan kajian.

3. Mengklasifikasikan data berdasarkan poin-poin permasalahan. Bahan-bahan yang telah ditelaah dikumpulkan lebih lanjut.

4. Mentafsirkan serta menganalisa data yang telah diklasifikasikan. Selanjutnya ditafsirkan serta di analisa sehingga dapat dipetik suatu kesimpulan yang tepat.

5. Menarik kesimpulan-kesimpulan yang akan diambil merupakan hasil dari analisa dengan membandingkan antara berbagai pendapat ahli tentang permasalahan yang dikaji.

\section{HASIL DAN PEMBAHASAN}

\section{Pengertian Psikologi Islam}

Pergulatan dalam pengembangan psikologi Islam masih terus terasa hingga sekarang.Memang sudah banyak forum ilmiah membicarakan hal ini.Paling tidak untuk konteks Indonesia, ada dua kelompok yang mencoba vgmembangun konsep psikologi Islam ini.

Psikologi Islam merupakan bagian dari psikologi yang mempelajari masalah-masalah kejiwaan yang ada sangkut pautnya dengan keyakinan beragama, dengan demikian psikologi agama mencakup 2 bidang kajian yang sama sekali berlainan, sehingga ia berbeda dari cabang psikologi lainnya Agama diartikan sebagai pengalaman dunia dalam seseorang tentang keTuhanan disertai keimanan dan peribadatan. Meski bagi sebagian orang, agama adalah ritual ibadah semata, seperti salat dan puasa, bagi yang lain agama adalah pengabdian kepada sesama manusia bahkan sesama makhluk, bagi yang lain lagi agama adalah akhlak atau perilaku baik, bagi yang lain lagi agama adalah pengorbanan untuk suatu keyakinan, berlatih mati sebelum mati, atau mencari mati (istisyhad) demi keyakinan.

Hanna Djumhana Bastaman, menjelaskan bahwa Psikologi Islam adalah: "Sebuah psikologi yang memiliki karakteristik dan identitas yang semuanya bermuara pada nilai-nilai Islam. Selain itu, psikologi Islam menggunakan akal dan keimanan sekaligus, yakni menggunakan secara optimal daya nalar yang obyektif-ilmiah dengan metodologi yang tepat" (Hanna Djumhana Bastaman, 2005: 14).

Psikologi Islam dalam tiga pengertian. Pertama, bahwa psikologi Islam merupakan salah satu dari kajian masalah-masalah keislaman.psikologi Islam memiliki kedudukan yang sama dengan disiplin ilmu keislaman yang lain, seperti Ekonomi Islam, Sosiologi Islam, Politik Islam, Kebudayaan Islam, dan sebagainya. Artinya, psikologi yang dibangun bercorak atau memiliki pola pikir sebagaimana yang berlaku pada tradisi keilmuan dalam Islam, sehingga dapat membentuk aliran tersendiri yang unik dan berbeda dengan psikologi kontemporer pada umumnya.

Kedua, bahwa Psikologi Islam membicarakan aspek-aspek dan perilaku kejiwaan manusia.Aspek-aspek kejiwaan dalam Islam berupa al-Ruh, al-Nafs, al-Kalb, al-`Aql, al-Damir, al-Lubb, al-Fu'ad, al-Sirr, al-Fitrah, dan sebagainya.Masing-masing aspek tersebut memiliki eksistensi, dinamisme, proses, fungsi, dan perilaku yang perlu dikaji melalui al-Qur'an, alSunnah, serta dari khazanah pemikiran Islam. Psikologi Islam tidak hanya menekankan perilaku kejiwaan, melainkan juga apa hakekat jiwa sesungguhnya. 
Ketiga, bahwa Psikologi Islam bukan netral etik, melainkan sarat akan nilai etik. Dikatakan demikian sebab Psikologi Islam memiliki tujuan yang hakiki, yaitu merangsang kesadaran diri agar mampu membentuk kualitas diri yang lebih sempurna untuk mendapatkan kebahagiaan hidup di dunia dan akhirat. Manusia dilahirkan dalam kondisi tidak mengetahui apa-apa, lalu ia tumbuh dan berkembang untuk mencapai kualitas hidup (Hanna Djumhana Bastaman. 2005: 17).

Sedang menurut Baharuddin, psikologi Islam adalah sebuah aliran baru dalam dunia psikologi yang mendasarkan seluruh bangunan teori-teori dan konsep-konsepnya kepada Islam (Baharuddin. 2005: 25).

Hakekat definisi tersebut mengandung tiga unsur pokok, yaitu:

a. Bahwa psikologi Islam merupakan salah satu dari kajian masalah-masalah keislaman. Ia memiliki kedudukan yang sama dengan disiplin ilmu keislaman yang lain, seperti Ekonomi Islam, Sosiologi Islam, Politik Islam, Kebudayaan Islam, dan sebagaianya. Penempatan kata "Islam" di sini memiliki arti corak, cara pandang, pola pikir, paradigma, atau aliran.Artinya, psikologi yang dibangun bercorak atau memilili pola pikir sebagaimana yang berlaku pada tradisi keilmuan dalam Islam, sehingga dapat membentuk aliran tersendiri yang unik dan berbeda dengan psikologi kontemporer pada umumnya. Tentunya hal itu tidak terlepas dari kerangka ontologi (hakekat jiwa), epistimologi (bagaimana cara mempelajari jiwa), dan aksiologi (tujuan mempelajari jiwa) dalam Islam. Melalui kerangka ini maka akan tercipta beberapa bagian psikologi dalam Islam, seperti Psikopatologi Islam, Psikoterapi Islam, Psikologi Agama Islam, Psikologi Perkembangan Islam, Psikologi Sosial Islam, dan sebagainya

b. Psikologi Islam membicarakan aspek-aspek dan perilaku kejiwaan manusia. Aspekaspek kejiwaan dalam Islam berupa al-ruh, al-nafs, al-kalb, al- aql, al-dhamir, allubb, al-fu'ad, al-sirr, al-fithrah, dan sebagainya. Masing-masing aspek tersebut memiliki eksistensi, dinamisme, proses, fungsi, dan perilaku yang perlu dikaji melalui al-Qur'an, al-Sunnah, serta dari khazanah pemikiran Islam. Psikologi Islam tidak hanya menekankan perilaku kejiwaan, melainkan juga apa hakekat jiwa sesungguhnya. Sebagai satu organisasi permanen, jiwa manusia bersifat potensial yang aktualisasinya dalam bentuk perilaku sangat tergantung pada daya upaya (ikhtiyar)-nya. Dari sini nampak bahwa psikologi Islam mengakui adanya kesadaran dan kebebasan manusia untuk berkreasi, berpikir, berkehendak, dan bersikap secara sadar, walaupun dalam kebebasan tersebut tetap dalam koredor sunnah-sunnah Allah Swt.

c. Psikologi Islam bukan netral etik, melainkan sarat akan nilai etik. Dikatakan demikian sebab Psikologi Islam memiliki tujuan yang hakiki, yaitu merangsang kesadaran diri agar mampu membentuk kualitas diri yang lebih sempurna untuk mendapatkan kebahagiaan hidup di dunia dan akhirat. Manusia dilahirkan dalam kondisi tidak mengetahui apa-apa, lalu ia tumbuh dan berkembang untuk mencapai kualitas hidup. Psikologi Islam merupakan salah satu disiplin yang membantu seseorang untuk memahami ekspresi diri, aktualisasi diri, realisasi diri, konsep diri, citra diri, harga diri, kesadaran diri, kontrol diri, dan evaluasi diri, baik untuk diri sendiri atau diri orang lain. Jika dalam pemahaman diri tersebut ditemukan adanya 
penyimpangan perilaku maka Psikologi Islam berusaha menawarkan berbagai konsep yang bernuasa ilahiyah, agar dapat mengarahkan kualitas hidup yang lebih baik, yang pada gilirannya dapat menikmati kebahagiaan hidup di segala zaman. Walhasil, mempelajari psikologi Islam dapat berimplikasi membahagiakan diri sendiri dan orang lain, bukan menambah masalah baru seperti hidup dalam keterasiangan, kegersangan, dan kegelisahan (Baharuddin. 2005: 65).

Dari uraian di atas dapat disimpulkan bahwa pengertian psikologi Islam adalah suatu ilmu yang mempelajari gejala kejiwaan manusia yang normal, dewasa dan beradab, dan didasarkan pada al-Quran sebagai sumber hukum Islam dan hakekatnya berhubungan dengan aspek-aspek dan perilaku kejiwaan manusia, agar secara sadar ia dapat membentuk kualitas diri yang lebih sempurna dan mendapatkan kebahagiaan hidup di dunia dan akhirat.

\section{Tujuan Psikologi Islam}

Telah dinyatakan dengan sangat jelas di dalam al-Qur'an bahwa ajaran Islam merupakan panduan kehidupan yang memiliki visi rahmatan lil'alamin. Artinya membawa berkah kebaikan bagi seluruh alam. Seluruh alam ini bermakna meliputi segala kehidupan yang melingkupi manusia, alam, tumbuh-tumbuhan, atau dengan arti lainnya adalah alam semesta.Dengan visi yang demikian tentu saja, ajaran Islam tidak main-main dalam memberikan guideline yang jelas bagi kehidupan manusia (Fuad Nashori, 2002: 112).

Karena itu dengan kodrat kuasa Allah yang Maha Rahman dan Maha Rahim, Allah berkehendak manusia dapat meraih kebaikan dalam kehidupan ini dan menjadi faktor yang dapat mengembangkan kebaikan yang lebih luas bagi kehidupan alam raya. Allah memberikan Islam sebagai way of life bagi kaum muslimin:

a. Allah telah menggariskan bahwa manusia merupakan hamba Allah. Dan tugas seorang hamba adalah mengabdi pada Tuhannya dengan sebenar-benarnya pengabdian. Terkait dengan pengabdian tersebut, maka ada tata cara atau aturan yang harus dilaksanakan agar pengabdian tersebut dapat memberikan pengaruh positif yang signifikan bagi si hamba. Karena itulah Allah memberikan petunjuk dan panduannya, yang berupa ajaran Islam. (Baharuddin. 2005: 53)

b. Allah juga telah mewariskan alam raya ini kepada manusia, agar manusia dapat memberikan kebaikan bagi alam semesta dengan mengelolanya sebaik mungkin bagi kehidupan manusia. Hasil yang diharapkan dari pengelolaan tersebut adalah tercapainya kebaikan bagi semua makhluk, kebahagiaan, dan ketentraman dalam kehidupan. Agar tujuan tersebut tercapai, maka Allah memberikan kriteria "mana yang disebut baik dan mana yang disebut buruk". Standar kebaikan atau keburukan tersebut bukan berdasarkan pandangan manusia, tetapi berdasarkan ketentuan yang telah digariskan oleh Allah. Mengapa demikian, karena "baik menurut manusia belum tentu baik menurut Allah, buruk menurut manusia belum tentu buruk menurut Allah. (Baharuddin. 2005: 54)

Dengan demikian tujuan psikologi Islam, adalah:

a. Berusaha memahami ajaran Islam agar dapat dipraktekkan dalam kehidupan seharihari. Sebab selama ini kita terlalu dikotomis dalam memahami ajaran Islam. Kita mengira bahwa ajaran Islam hanya berlaku untuk peribadatan semata. Jadi kalau kita 
mau sholat, puasa, haji, zakat, syahadat, baru kita bicara ajaran Islam. Tetapi pada saat kita bekerja, belajar, berinteraksi, berkreasi, kita menganggap bahwa itu bukan lagi ranah ajaran Islam. Padahal ajaran Islam melingkupi tatacara ibadah (ubudiyah) dan aktivitas kemanusiaan (muamalah).

b. Memahami bahwa ajaran Islam bukanlah ajaran langit yang sangat tinggi dan mengawang-awang, apalagi abstrak. Ajaran Islam sangatlah membumi, tidak dibuat rumit untuk dipahami, konkrit, dan realistis. Mengapa demikian ? Karena ajaran Islam dianugerahkan kepada manusia, tentu saja bahasanya adalah bahasa manusia, pemahamannya adalah pemahaman manusia, pengaplikasiannya adalah untuk manusia.

c. Menjadikan ajaran Islam sebagai objek keilmuan yang dapat kita ukur dan evaluasi naik dan turunnya keyakinan dan praktek keimanan kita umat Islam.

d. Menggunakan ajaran Islam sebagai alat untuk mempermudah tugas dan visi manusia menjadi perpanjangan tangan Allah bagi kemaslahatan alam semesta.

Dari uraian di atas dapat disimpulkan bahwa tujuan psikologi Islami adalah membantu orang-orang menjadi sehat mentalnya dan sekaligus meningkatkan keimanan dan ketakwaannya menjadi mukmin dan muttaqin, atau dengan ungkapan bahwa misi besar psikologi Islami adalah menyelamatka manusia untuk memenuhi kecenderungan alaminya untuk kembali pada-Nya dan mendapat ridha-Nya. Sedangkan tujuan dari psikologi Islami yaitu tidak saja mengembangkan kesehatan mental pada diri pribadi dan masyarakat melainkan juga meningkatkan keimanan dan ketakwaan kepada Allah SWT.

\section{Konsep Pendidikan Karakter Ditinjau Presfektif Psikologi Islam}

Dalam dunia tasawuf, psikologi dikembangkan bukan hanya untuk tujuan teoritis belaka.Melainkan untuk melakukan transformasi jiwa. Karena bagi sufi transformasi jiwa merupakan hal yang paling urgen dalam suatu disiplin ilmu. Ilmu yang tidak menghasilkan sebuah transformasi jiwa akan dipandang rendah, bagaimanapun sistematisnya ia secara teoritis. J. Rumi dikutip dalam buku Aktualisasi Psikologi Islam karangan Baharuddin yaitu pernah mengeritik teologi dan fiqh karena kecendrungannya pada "formalisme". Ia gagal dalam melakukan transformasi jiwa. Hanya tasawuflah yang akan mampu melakukan transformasi jiwa seseorang. (Baharuddin. 2005: 51)

Sepanjang sejarah pemikiran tasawuf, banyak teori psikologi yang dikembangkan oleh para sufi. Istilah-istilah yang dikemukakan oleh para sufi juga berbeda-beda. Tetapi sudah menjadi semacam kesepakatan bahwa psikologi sufi berkisar pada tiga konsepsi dasar kejiwaan. Yaitu, hati, diri (nafs), dan jiwa (ruh)

Psikologi atau 'ilm al-nafs dalam pandangan Imam Al-Ghazali (w.505H/1111M) (AlGhazali,1993:76) , termasuk dalam kategori ilmu-ilmu terapan. Psikologi pada hakekatnya bertujuan melatih jiwa dan pengendalian hawa nafsu. Termasuk dalam hal ini adalah bagaimana melatih jiwa dalam bermuamalah kepada seluruh anggota keluarga, pembantu dan budak.

Dalam sejarah pemikiran filsafat dan keagamaan Islam, Al-Ghazali menempati kedudukan yang sangat unik, karena pertimbangan kedalaman pengetahuannya, orisinilitas, dan pengaruh pemikirannya. Sehingga ia dijuluki the proof of Islam (hujjat al-Islam), the ornament of faith (zain al-din), dan the renewer of religion (mujaddid). Juga dalam dirinya terkumpul 
hampir semua jenis pemikiran dari berbagai gerakan intelektual dan keagamaan. Maka, tidaklah mengherankan jika ia terkenal sebagai seorang pakar dalam berbagai disiplin ilmu seperti teologi, fikih, filsafat, dan tasawuf (Ahmadi, 2003: 23).

Dalam kitabnya Ihya 'Ulumiddin, beliau menjelaskan bahwa mempelajari disiplin ilmu jiwa ini adalah wajib.Sebab dengan menguasai ilmu inilah tercapainya cara-cara pensucian jiwa."Sesungguhnya beruntunglah orang yang mensucikan jiwa itu" (QS. 91:9). Sedangkan mengabaikan ilmu ini akan berakhir pada kerugian. "Dan sesungguhnya merugilah orang yang mengotori jiwanya" (QS. 91:10).Hal ini dikarenakan bahaya penyakit kalbu lebih parah daripada penyakit fisik.Sebab penyakit fisik hanya merenggut kehidupan yang fana, sementara penyakit hati menyebabkan kehancuran pada kehidupan yang abadi.Maka perhatian terhadap kecermatan tentang kaedah-kaedah penyembuhan penyakit kalbu harus lebih diutamakan (Al-Ghazali, (Mukhtashar Ihya Ulum al-Din, terj.Irwan Kurniawan, 1993: 39).

Psikologi menurut al-Ghazali adalah ilmu yang mengkaji tentang jiwa.Ia menganggap bahwa pengetahuan mengenai jiwa merupakan jalan untuk mengetahui tentang Allah (Ma'rifatullah). Ia menyebutkan bahwa jejak-jejak di mana dapat terlihat keagungan Sang pemilik kebenaran dan kesempurnaan sifat adalah ma'rifat jiwa.

Dalam kajiannya tentang jiwa, terdapat dua macam psikologi yaitu psikologi yang membahas tentang daya jiwa hewan, daya manusia, daya penggerak dan daya jiwa sensoris, dan kedua adalah psikologi yang membahas tentang olah jiwa, perbaikan akhlak dan terapi akhlak tercela. Jadi jiwa bisa diartikan adalah kesempurnaan pertama (tidak melalui kesempurnaan yang lain) bagi fisik alamiah (bukan bersifat buatan) yang sifatnya mekanistik (memiliki alat-alat tertentu yang dipakai oleh kesempurnaan tersebut untuk memperoleh kesempurnaan berikutnya). (Imam Al-Ghazali, Misykat 1993: 285).

Pendidikan karakter merupakan upaya-upaya yang dirancang dan dilaksanakan secara sistematis untuk membantu peserta didik memahami nilai-nilai perilaku manusia yang berhubungan dengan Tuhan Yang Maha Esa, diri sendiri, sesama manusia, lingkungan, dan kebangsaan yang terwujud dalam pikiran, sikap, perasaan, perkataan, dan perbuatan berdasarkan norma-norma agama, hukum, tata krama, budaya, dan adat istiadat.

Disamping itu, pendidikan karakter juga merupakan upaya untuk membekali peserta didik melalui kegiatan bimbingan, pengajaran dan latihan selama pertumbuhan dan perkembangan dirinya sebagai bekal bagi masa depannya, agar memiliki hati nurani yang bersih, berperangai baik, serta menjaga kesusilaan dalam melaksanakan kewajiban terhadap Tuhan dan terhadap sesama makhluk, sehingga terbentuk pribadi seutuhnya yang tercermin pada perilaku berupa ucapan, perbuatan, sikap, pikiran, perasaan, kerja dan hasil karya berdasarkan nilai-nilai agama serta norma dan moral luhur bangsa.

Pendidikan karakter rmenurut Islam dapat dijalankan dengan memberikan berbagai contoh teladan, pembiasaan, latihan, anjuran dan larangan, kemudian diberikan penjelasan dan pengertian sesuai dengan taraf pemikirannya tentang norma dan nilai-nilai kemasyarakatan, kesusilaan dan keagamaan. Kemudian tumbuhkan tindakan, sikap, pandangan, pendirian, keyakinan dan kesadaran serta kepercayaan untuk berbuat sesuatu yang bertanggung jawab akhirnya terbentuklah kata hati (kerohanian yang luhur) pada anak pada masa dewasanya. Disamping itu, pendidikan karakter dapat dilakukan dengan membina nilai-nilai kemasyarakatan, 
kesusilaan dan keagamaan yang disatupadukan, sehingga terwujud sikap, mental, akhlak dan kepribadian yang sesuai dengan ajaran agama Islam.

Dari penjelasan di atas dapat di analisa bahwa pendidikan karakter sangat erat kaitannya dengan psikologi Islam. Di samping itu, pendidikan karakter berbasis psikologi Islam akan membawa keberhasilan dalam mewujudkan pendidikan karakter karena psikologi Islam akan mengantarkan para pendidik lebih memahami karakter anak didik baik yang berkaitan dengan mental dan kondisi jiwanya, sehingga penanaman pendidikan karakter pada anak didik akan lebih tercapai. Pendidikan karakter berbasis psikologi akan mewujudkan anak didik memilikimemiliki hati nurani yang bersih, berperangai baik, serta menjaga kesusilaan dalam melaksanakan hal-hal yang berhubungan dengan Allah (Hablumminallah) dan berhubungan dangan sesama manusia (Hablumminannas).

\section{KESIMPULAN}

Pendidikan karakter merupakan pendidikan yang berorientasi pada tingkah laku dan akhlak terpuji serta tata krama yang berisikan kebiasaan sopan santun yang disepakati dalam lingkungan pergaulan antar manusia. tujuan pendidikan karakter yaitu meningkatkan keimanan, pemahaman, penghayatan dan pengalaman seseorang terhadap ajaran islam sehingga menjadi orang muslim yang bertakwa kepada Allah SWT serta berakhlak mulia dalam kehidupan pribadi, bermasyarakat, berbangsa dan bernegara. Sementara psikologi Islam adalah: suatu ilmu yang mempelajari gejala kejiwaan manusia yang normal, dewasa dan beradab, dan didasarkan pada alQuran sebagai sumber hukum Islam dan hakekatnya berhubungan dengan aspek-aspek dan perilaku kejiwaan manusia, agar secara sadar ia dapat membentuk kualitas diri yang lebih sempurna dan mendapatkan kebahagiaan hidup di dunia dan akhirat.

\section{DAFTAR PUSTAKA}

Al-Ghazali. (2001). Mutiara Ihya Ulumuddin. Terj Iwan Kurniawan, Bandung: Mizan . (2002). Akhlak Mulia Rasulullah, Jakarta: Nahjul . (2003). Tahafut Al-1Falasifah.Yogyakarta: Islamika

Ahmadi (2003). Telaah Hakikat Manusia Menurut Para Filosof Musliom Klasik (Sebuah

Tinjauan Paedagogik )", Jurnal Studi Islam, Program Pasca-Sarjana IAIN ArRaniry, Banda Aceh, 01, (2)8-9

Baharuddin. (2005). Aktualisasi Psikologi Islam, Yogyakarta: Pustaka Pelajar Darwis A. Sulaiman. (1979). Pengantar Kepada Teori dan Praktek, Cet I, Semarang: Press

Fathiyah Hasan Sulaiman.(1986). Konsep Pendidikan Al-Ghazali, terj. Ahmad Hakim dan M. Imam Aziz, Jakarta: Guna Aksara

Fuad Nashori. (2002). Agenda Psikologi Islam, Yogyakarta: Pustaka Pelajar Hanna Djumhana Bastaman. (2005). Integrasi Psikologi dengan Islam Menuju Psikologi Islam, Yogyakarta: Pustaka Pelajar

Imam Al-Ghazali. (1993). Misykat Cahaya-cahaya terj.M. Bagir, Bandung: Mizan Sidi Gazalba. (2001)Modernisasi dan Persoalanya, Jakarta, Toha Putra 